\title{
Establishment and Evaluation of a New Chemiluminescent Enzyme Immunoassay for Carcinoembryonic Antigen Adapted to the Fully Automated ACCESS ${ }^{\circledR}$ System
}

\author{
Hirotoshi Matsushita ${ }^{1}$, Xu Jingzhi ${ }^{1}$, Masahide Kuroki ${ }^{2}$, Akira Kondo', Emiko Inoue ${ }^{1}$, Yasuo Teramura', \\ Masaynki Nozawa', Tarumi Senba', Takafumi Yamamoto ${ }^{2}$ and Yuji Matsuoka ${ }^{2}$ \\ 1 Tokai R \& D Laboratories, Daiichi Pure Chemicals Co., Ltd., Tokai, Ibaraki, Japan \\ ${ }^{2}$ First Department of Biochemistry, School of Medicine, Fukuoka University, Fukuoka, Japan
}

Summary: We have established a new chemiluminescent enzyme immunoassay for carcinoembryonic antigen (CEA), designated ACCESS CEA, which is adapted to the fully automated ACCESS ${ }^{\circledR}$ immunoassay analyzer. The assay is based on a one step sandwich-type method using two monoclonal antibodies, one of which is immobilized on micrometer-size paramagnetic particles and the other is conjugated to alkaline phosphatase. Ten microliters of calibrators or sera are incubated for 5 minutes at $37^{\circ} \mathrm{C}$ with the particles and with the alkaline phosphatase conjugate. The particles are then magnetically separated and washed to remove unbound components. Time needed to obtain the first result is less than 15 minutes.

The assay range was $0.04-1000 \mu \mathrm{g} / \mathrm{l}$ of CEA, and the possible high-dose hook effect was prevented at CEA concentrations up to $100000 \mu \mathrm{g} / \mathrm{l}$ in this working range. The coefficient of variation (CV) for intra-assay precision was 3.0 to $4.7 \%$, and inter-assay CV was 3.4 to $5.6 \%$. The sample carryover was less than $0.001 \%$. The analytical recovery ranged from 98 to $104 \%$ and a dilution linearity was demonstrated. No interference was detected in any sample with levels up to $300 \mathrm{mg} / \mathrm{l}$ for bilirubin, $12000 \mathrm{mg} / \mathrm{l}$ for haemoglobin, $50000 \mathrm{mg} / \mathrm{l}$ for human serum albu$\mathrm{min}, 8500 \mathrm{mg} / \mathrm{l}$ for triacylglycerol, and $500000 \mathrm{IU} / \mathrm{l}$ for rheumatoid factor. The ACCESS CEA assay also showed very homogeneous reactivity with purified CEA preparations from different tumours and could discriminate CEA from four CEA-related normal antigens tested.

Serum samples $(n=362)$ from patients with malignant or non-malignant disease, as well as from healthy individuals, were analyzed by the ACCESS CEA assay and by the established IMx CEA assay. The CEA values determined by the ACCESS CEA assay were in good agreement with those determined by the IMX CEA assay, and the ACCESS CEA assay significantly increased the sensitivity and specificity of tumour diagnosis as compared with the IMx CEA assay.

\section{Introduction}

Carcinoembryonic antigen (CEA) is a heavily glycosylated protein of the immunoglobulin gene superfamily with a relative molecular mass of 180000 (1). The CEA peptide is composed of an N-terminal domain $(\mathrm{N})$ and six very homologous immunoglobulin constant regionlike domains (A1, B1, A2, A3 and B3) (1). The measurement of CEA levels in blood is considered a useful laboratory aid for the management of patients with various cancers (2).

Although various immunoassay systems for CEA are currently available, the CEA values obtained are highly variable depending on the assay kit used $(3-5)$. This is thought to be due to the diverse structures of the carbohydrate chains of the CEA molecule $(6,7)$, which lead to variation in specificity of anti-CEA antibody preparations used in the assay kits (8). On the other hand, about
20 CEA-related antigens, such as non-specific cross-reacting antigens and normal faecal antigens, have been detected in many tissues unrelated to malignant diseases (1). Thus, it seems important to improve the accuracy of the CEA assays by selecting monoclonal antibodies which are independent of the influence of variations in the carbohydrate chains and are not cross-reactive with the CEA-related antigens (5). In previous studies, Kuroki et al. have generated 146 anti-CEA monoclonal antibodies and clarified in detail their reactivities with CEA and main CEA-related antigens $(9,10)$. Furthermore, these monoclonal antibodies have been classified into 7 groups (groups $A-G$ ) in light of the domain structure of the CEA molecule $(11,12)$. Among them, group $\mathrm{F}$ monoclonal antibodies have been found to discriminate CEA in tumour tissues from the CEA-related antigens (13). The immunoassay systems for CEA utilizing at least one 
group $F$ monoclonal antibody have shown improved cancer diagnosis $(14,15)$.

Recent attempts, however, have concentrated on the development of automated immunoassay analyzers with sensitive and precise assay reagents, which also reduce turn-around time, stuff usage and volume of disposables and assay costs, and several automated non-isotopic immunoassay systems have been introduced for estimation of various analytes including CEA (16). Of these, the ACCESS ${ }^{\circledR}$ immunoassay analyzer (Sanofi Diagnostics Pasteur, Inc., Chaska, MN, USA) is a fully automated laboratory assay system for enzyme immunoassays (EIAs) with the term random access relating to the concept of flexible assay processing and with continuous access i.e., the ability to interrupt an analyzer run, add stat or additional routine specimens, and continue the run with no loss of results $(16,17)$.

In the present study, by using two defined monoclonal antibodies, including a .Group $\mathrm{F}$ monoclonal antibody, we tried to establish a new immunoassay for CEA, designated ACCESS CEA, which is adapted to the fully automated ACCESS ${ }^{\circledR}$ immunoassay analyzer. We further evaluated the ACCESS CEA assay in the CEA determinations of patients' serum samples, and compared it with the established IMx CEA assay.

\section{Materials and Methods}

Carcinoembryonic antigen and related normal antigens

Four different CEA preparations, designated CEA-DB, CEA-MY, CEA-TT, and CEA-TY, were purified from liver metastases from colorectal carcinomas by treatment with phosphatidylinositol-specific phospholipase $\mathrm{C}$ followed by perchloric acid extraction and gel filtration as previously described (18). Non-specific cross-reacting antigen and non-specific cross-reacting antigen-2 were purified from pooled normal human lung (19) and meconium (20), respectively. Normal faecal antigen-1 and normal faecal antigen- 2 were obtained from normal adult faeces (21). The non-specific crossreacting antigen and normal faecal antigen- 1 are partially crossreactive with CEA but antigenically unrelated to each other (22). The purity of each antigen preparation was ensured by the demonstration of a single component on immunoelectrophoresis and by sodium dodecyl sulphate polyacrylamide gel electrophoresis (20, 21 ), and was also defined by a single $\mathrm{NH}_{2}$-terminal amino acid $(22,23)$. The concentrations in weight of all antigens were estimated from the absorption coefficient of each antigen (5).

\section{Monoclonal antibodies}

Two mouse anti-CEA monoclonal antibodies (F82-61 and F11-39) were prepared as described by Kuroki et al. $(10,12)$. Both monoclonal antibodies were of IgG1 (12). The monoclonal antibodies were purified from ascitic fluids by ammonium sulphate precipitation and protein A chromatography. Purified monoclonal antibody F82-61 was immobilized on micrometre-size paramagnetic particles (Rhone-Poulenc Chimie, Lyon Cedex, France) as capture antibody as described previously (24). The antibody fragment Fab' of monoclonal antibody F11-39 was prepared with pepsin digestion followed by gel filtration on a TSK G3000SW column and reduction with 2-mercaptoethylamine $\mathrm{HCl}$ as described by Hashida et al. with slight modifications (25), and conjugated to alkaline phosphatase (Boehringer Mannheim GmbH, Mannheim, Germany) as tracer antibody.

\section{Instruments}

The ACCESS ${ }^{\circledR}$ immunoassay analyzer has a unique solid-phase washing procedure and a chemiluminescent detection system (16, 17). These provide for immunoassays characterized by high sensitivity and/or broad dynamic working ranges. During the wash cycles. magnets are used to pull the paramagnetic particles to the side of the rcaction vessel to allow complete aspiration of the wash fluid. The particles are resuspended by forcefully adding buffer and then gently agitating the vessel. The ACCESS system assays use Lumi-Phos 530 (Lumigen, Inc., Detroit, MI, USA), a dioxetanebased chemiluminescent substrate, which is dephosphorylated upon the addition of alkaline phosphatase, resulting in the release of light. The light emitted is measured by the luminometer and the system converts the signals (relative luminescence units: RLUs) into a sample test result.

Commercial enzyme immunoassay for carcinoembryonic antigen

A commercially available EIA kit, Abbott IMx ${ }^{\circledR}$ CEA (Dainabot Co., Tokyo, Japan), was used for comparative studies. The assay employed as sandwich-type method with two different monoclonal antibodies and was performed according to the instructions of the manufacturer.

\section{Serum samples}

Sera from patients with various malignant or benign diseases and from healthy individuals were collected and stored at $-20^{\circ} \mathrm{C}$ until use.

\section{Interfering substances}

Bilirubin, haemoglobin, rheumatoid factor and triacylglycerol were obtained from International Reagents Corp. (Kobe, Japan); and human serum albumin from Sigma Chemical Co. (St. Louis, MO, USA).

\section{Results}

\section{Assay protocol obtained}

Ten microlitres of calibrators or sera and $40 \mu$ lof the diluent are incubated for 5 minutes at $37^{\circ} \mathrm{C}$ with $50 \mu \mathrm{l}$ of monoclonal antibody F82-61-immobilized particles and with $50 \mu \mathrm{l}$ of monoclonal antibody F11-39 Fab' conjugated with alkaline phosphatase. To eliminate interference from human anti-mouse immunoglobulin antibody, the diluent contains $250 \mathrm{mg} / \mathrm{l}$ of Heterophilic Blocking Reagent (Scantibodies Laboratories, Santee, CA, USA), which is a mixture of purified mouse IgG subclasses. After washing the unbound components, $200 \mu$ lof the Lumi-Phos ${ }^{\circledR} 530$ solution are added and the particles are incubated for 5 minutes at $37^{\circ} \mathrm{C}$. Time needed to obtain the first result is less than 15 minutes and thereafter one result is obtained every thirty-six seconds. Results are interpolated automatically from a previously run stored standard curve (stable for up to four weeks).

\section{Dose-response curve, detection limit, and} hook effect

The CEA calibrators with the concentrations ranging from 0 to $100000 \mu \mathrm{g} / \mathrm{l}$ were tested. Figure 1 represents a typical dose-response curve in which the luminescence obtained is plotted against the CEA calibrator concentra- 


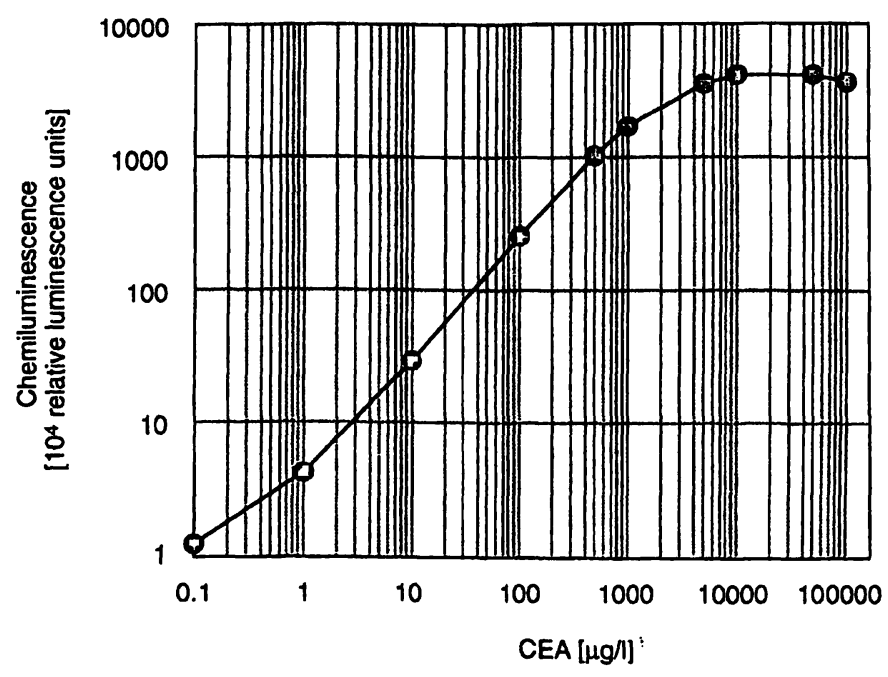

Fig. 1 Typical calibration curve obtained by the ACCESS CEA assay. Note that the first point against the zero calibrator is not included because of logarithmic scale.

tion. The detection limit of the assay, defined as the concentration of CEA equivalent to the mean luminescence plus 2 standard deviations of the zero calibrator, was calculated based on the respective 10 measurements on three different instruments and found to be $0.04 \mu \mathrm{g} / 1$. Although the dose-response curve extended up to about $10000 \mu \mathrm{g} / \mathrm{l}$, moderate high-dose hook effect was observed with the concentrations of 50000 and 100000 $\mu \mathrm{g} / \mathrm{l}$ (fig. 1). Therefore, the concentrations of calibrators ranging from 0 to $1000 \mu \mathrm{g} / \mathrm{l}$ were selected for determination of CEA in serum samples because in this working range it is virtually impossible to underestimate the concentration due to the hook effect except when the concentration is extremely high $(>100000 \mu \mathrm{g} / \mathrm{l})$.

\section{Precision study}

The intra-assay precision was determined by replication $(n=20)$ of three serum samples with different CEA levels. To assess inter-assay precision, three concentrations of control sera were assayed in duplicate in at least 20 runs over a period of four weeks. As shown in table 1 , the intra-assay CV ranged from 3.0 to $4.7 \%$, while inter-assay CV ranged from 3.4 to $5.6 \%$.

Tab. 1 Intra- and inter-assay precision using control sera.

\begin{tabular}{|c|c|c|c|c|c|}
\hline \multicolumn{3}{|c|}{ Intra-assay precision ${ }^{a}$} & \multicolumn{3}{|c|}{ Inter-assay precision ${ }^{b}$} \\
\hline $\begin{array}{l}\text { Mean } \\
(\mu \mathrm{g} / \mathrm{l})\end{array}$ & $\begin{array}{l}\text { SD } \\
(\mu \mathrm{g} / \mathrm{l})\end{array}$ & $\begin{array}{l}\text { CV } \\
(\%)\end{array}$ & $\begin{array}{l}\text { Mean } \\
(\mu \mathrm{g} / \mathrm{l})\end{array}$ & $\begin{array}{l}\text { SD } \\
(\mu \mathrm{g} / \mathrm{l})\end{array}$ & $\begin{array}{l}\text { CV } \\
(\%)\end{array}$ \\
\hline 4.5 & 0.2 & 4.7 & 5.1 & 0.2 & 3.4 \\
\hline 46.4 & 1.4 & 3.0 & 49.0 & 1.8 & 3.7 \\
\hline 483.4 & 21.6 & 4.5 & 497.3 & 27.7 & 5.6 \\
\hline
\end{tabular}

a Three concentrations of control sera were measured $(n=20)$ in one assay.

b Three concentrations of control sera were measured in duplicate over four weeks ( $n=20$ runs).

\section{Carryover}

The carryover was checked by running a serum sample spiked with a high amount of CEA $(10000 \mu \mathrm{g} / \mathrm{l})$. After analyzing 4 replicates of the zero calibrator, 4 replicates of the sample were then analyzed, as well as 4 replicates of the zero calibrator. The first replicate of the zero calibrator, immediately after the sample, could then be read. Three values obtained by 3 runs were all $<0.1 \mu \mathrm{g} / \mathrm{l}$, indicating that the carryover was less than $0.001 \%$.

\section{Recovery}

The recovery of the assay was also determined by spiking known quantities of CEA to 4 different serum samples, assaying the serum samples and determining the recovery of the amount added. As shown in table 2, analytical recovery ranged from 98 to $104 \%$.

\section{Dilution}

Three different serum samples containing elevated concentrations of CEA within the assay range were diluted in the calibrator diluent. The samples and their dilutions were then assayed to determine linearity on dilution. Good linearity was observed in each case (fig. 2).

\section{Interference}

Assay interference was assessed by measuring the apparent response of the ACCESS CEA assay to various concentrations of potential interfering substances spiked into human sera. The basal sera and the spiked serum samples were then assayed. As shown in table 3, no interference was demonstrated in any sample with levels

Tab. 2 Analytical recovery of carcinoembryonic antigen (CEA).

\begin{tabular}{|c|c|c|c|c|c|}
\hline $\begin{array}{l}\text { Serum } \\
\text { No. }\end{array}$ & $\begin{array}{l}\text { Endogenous } \\
\mathrm{CEA} \\
(\mu \mathrm{g} / \mathrm{l})\end{array}$ & $\begin{array}{l}\text { CEA } \\
\text { spiked } \\
(\mu \mathrm{g} / \mathrm{l})\end{array}$ & $\begin{array}{l}\text { CEA } \\
\text { expected } \\
(\mu g / 1)\end{array}$ & $\begin{array}{l}\text { CEA } \\
\text { measured } \\
(\mu \mathrm{g} / \mathrm{l})\end{array}$ & $\begin{array}{l}\text { Rec- } \\
\text { overy }^{a} \\
(\%)\end{array}$ \\
\hline A & 12.0 & $\begin{array}{r}2.5 \\
5.0 \\
7.5 \\
10.0\end{array}$ & $\begin{array}{l}14.5 \\
17.0 \\
19.5 \\
22.0\end{array}$ & $\begin{array}{l}14.3 \\
16.7 \\
20.0 \\
21.8\end{array}$ & $\begin{array}{r}98 \\
98 \\
102 \\
99\end{array}$ \\
\hline B & 45.7 & $\begin{array}{r}2.5 \\
5.0 \\
7.5 \\
10.0\end{array}$ & $\begin{array}{l}48.2 \\
50.7 \\
53.2 \\
55.7\end{array}$ & $\begin{array}{l}48.8 \\
50.9 \\
52.2 \\
56.8\end{array}$ & $\begin{array}{r}101 \\
100 \\
98 \\
102\end{array}$ \\
\hline C & 116.5 & $\begin{array}{r}12.5 \\
25.0 \\
50.0 \\
100.0\end{array}$ & $\begin{array}{l}129.0 \\
141.5 \\
166.5 \\
216.5\end{array}$ & $\begin{array}{l}133.8 \\
146.9 \\
164.8 \\
215.8\end{array}$ & $\begin{array}{r}104 \\
104 \\
99 \\
100\end{array}$ \\
\hline D & 594.3 & $\begin{array}{r}25.0 \\
50.0 \\
75.0 \\
100.0\end{array}$ & $\begin{array}{l}619.3 \\
644.3 \\
669.3 \\
694.3\end{array}$ & $\begin{array}{l}618.0 \\
633.4 \\
659.2 \\
688.7\end{array}$ & $\begin{array}{r}100 \\
98 \\
99 \\
99\end{array}$ \\
\hline
\end{tabular}

a The percentage of recovery was defined as the ratio of the CEA measured divided by the CEA expected, multiplied by 100 ! 


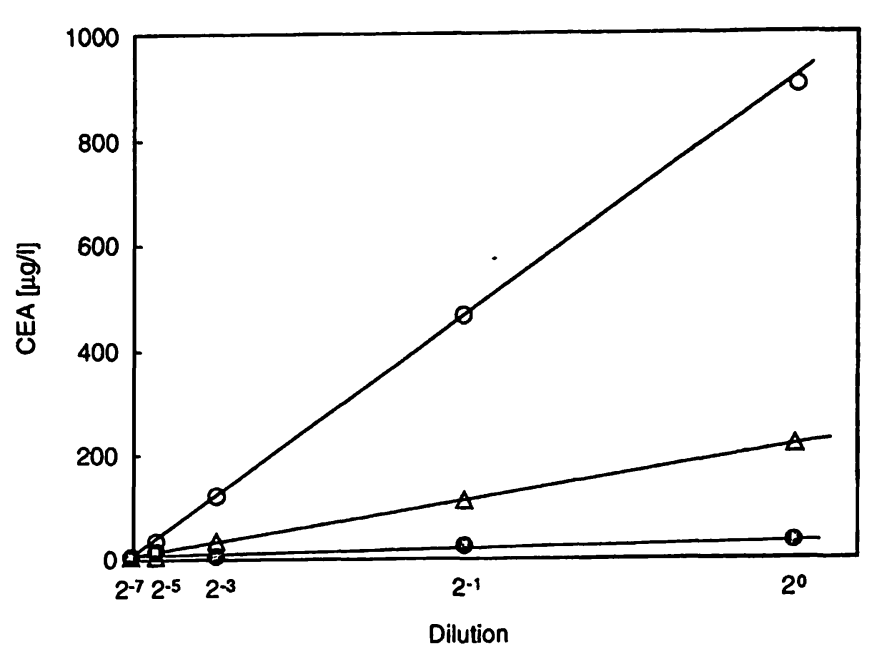

Fig. 2 Dilution test for the ACCESS CEA assay. Three patients' sera with CEA values of $28.9(\bullet), 221.0(\Delta)$ and $902.0 \mu \mathrm{g} / \mathrm{l}(0)$ were diluted with the zero calibrator buffer.

up to $300 \mathrm{mg} / \mathrm{l}$ for bilirubin, $12000 \mathrm{mg} / \mathrm{l}$ for haemoglobin, $50000 \mathrm{mg} / \mathrm{l}$ for human serum albumin, $8500 \mathrm{mg} / \mathrm{l}$ for triacylglyerol, or $500000 \mathrm{IU} / \mathrm{l}$ for rheumatoid factor.

\section{Reactivity with carcinoembryonic antigens and related normal antigens}

As shown in figure 3, the ACCESS CEA assay gave no reaction with non-specific cross-reacting antigen (NCA), NCA-2, normal faecal antigen (NFA)-1, and NFA-2.

Tab. 3 Assay interference

\begin{tabular}{|c|c|c|c|c|}
\hline $\begin{array}{l}\text { Interference } \\
\text { substance }\end{array}$ & $\begin{array}{l}\text { Inter- } \\
\text { ference } \\
\text { spiked } \\
\text { (mg/l) }\end{array}$ & $\begin{array}{l}\text { Endo- } \\
\text { genous } \\
\text { CEA } \\
(\mu \mathrm{g} / \mathrm{l})\end{array}$ & $\begin{array}{l}\text { CEA } \\
\text { measured } \\
(\mu \mathrm{g} / \mathrm{l})\end{array}$ & $\begin{array}{l}\begin{array}{l}\text { Rec- } \\
\text { overy }^{a}\end{array} \\
(\%)\end{array}$ \\
\hline Bilirubin & $\begin{array}{r}50 \\
150 \\
500\end{array}$ & 4.1 & $\begin{array}{l}4.2 \\
4.0 \\
4.0\end{array}$ & $\begin{array}{r}102 \\
98 \\
98\end{array}$ \\
\hline Haemoglobin & $\begin{array}{r}2000 \\
4000 \\
8000 \\
12000\end{array}$ & 4.1 & $\begin{array}{l}4.1 \\
4.0 \\
3.9 \\
4.1\end{array}$ & $\begin{array}{r}100 \\
98 \\
95 \\
100\end{array}$ \\
\hline $\begin{array}{l}\text { Human serum } \\
\text { albumin }\end{array}$ & $\begin{array}{l}10000 \\
20000 \\
30000 \\
40000 \\
50000\end{array}$ & 6.2 & $\begin{array}{l}6.2 \\
6.2 \\
6.2 \\
6.2 \\
6.1\end{array}$ & $\begin{array}{r}100 \\
100 \\
100 \\
100 \\
98\end{array}$ \\
\hline Triacylglycerol & $\begin{array}{l}1062 \\
2125 \\
4250 \\
8500\end{array}$ & 4.1 & $\begin{array}{l}4.3 \\
4.3 \\
4.3 \\
4.2\end{array}$ & $\begin{array}{l}105 \\
105 \\
105 \\
102\end{array}$ \\
\hline Rheumatoid factor & $\begin{array}{l}100000^{b} \\
200000^{b} \\
300000^{b} \\
400000^{b} \\
500000^{b}\end{array}$ & 6.5 & $\begin{array}{l}6.6 \\
6.6 \\
6.7 \\
7.1 \\
6.8\end{array}$ & $\begin{array}{l}102 \\
102 \\
103 \\
110 \\
105\end{array}$ \\
\hline
\end{tabular}

a The percentage of recovery was defined as the ratio of the CEA measured divided by the endogenous CEA, multiplied by 100 !
Furthermore, the ACCESS CEA assay showed quite homogeneous reactivity with all CEA preparations tested (fig. 3).

\section{Normal cutoff level}

The normal cutoff level was determined by analyzing sera from 477 healthy blood donors including smokers aged from 18 to 82 years, showing the values ranging from 0.2 to $9.9 \mu \mathrm{g} / \mathrm{l}$ and the average value of $2.03 \mu \mathrm{g} / \mathrm{l}$. Since $5 \mu \mathrm{g} / \mathrm{l}$ defined the 95th percentile in the ACCESS CEA assay and the kit documentation of the IMx CEA assay demonstrates a similar distribution of CEA values in reference populations, we therefore used a tentative common reference limit of $5 \mu \mathrm{g} / \mathrm{l}$ for both the ACCESS CEA and the IMx CEA assays.

\section{Clinical evaluation of the ACCESS CEA}

assay and comparison with a commercial kit

Serum samples of 133 patients with malignant disease and 72 patients with benign disease as well as of 157 normal subjects were tested with the ACCESS CEA and IMx CEA assays. The regression analyses of the ACCESS CEA assay with the IMx CEA assay showed satisfactory correlations, although the correlation coefficient (r) in sera from normal subjects is slightly lower than those in sera from benign or malignant disease (fig. 4). However, when frequency of elevated CEA levels for respective diseases was compared, some differences were seen between the ACCESS CEA assay and the IMx CEA assay (tab. 4). It is evident that the total positive rate for malignant disease showed an definite increase with the ACCESS CEA assay (56.4\%) compared to that of the IMx CEA assay (48.9\%). In gastric cancer, colorectal cancer, lung cancer, and hepatoma,

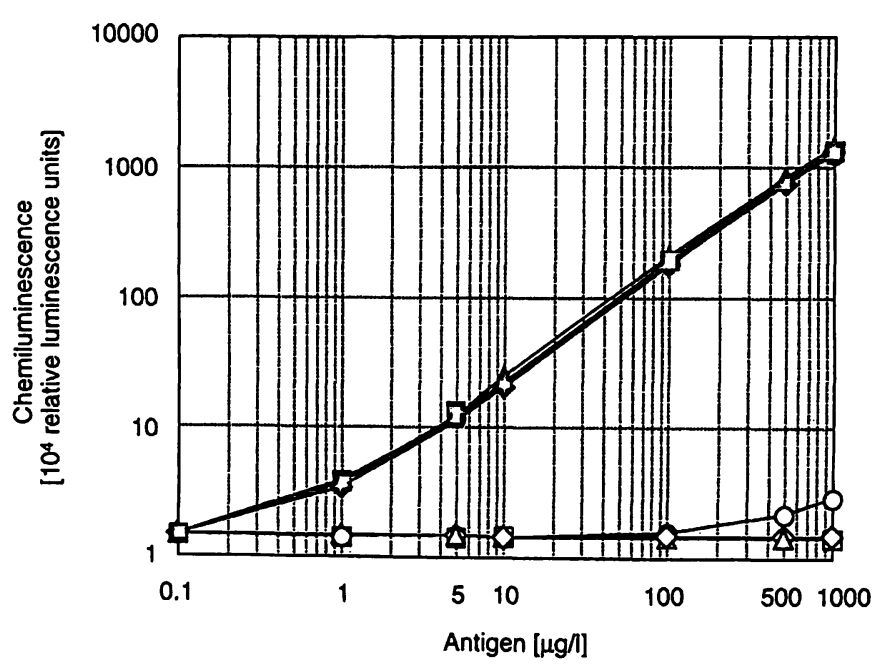

Fig. 3 Reactivity of carcinoembryonic antigens (CEAs) and related normal antigens in the ACCESS CEA assay. Antigens tested:

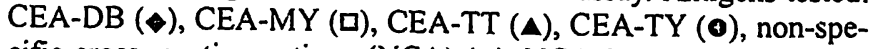
cific cross-reacting antigen (NCA) $(\square)$, NCA-2 $(\diamond)$, normal faecal antigen (NFA)-1 $(\triangle)$, and NFA-2 (0). The first point against the zero calibrator is not included. 

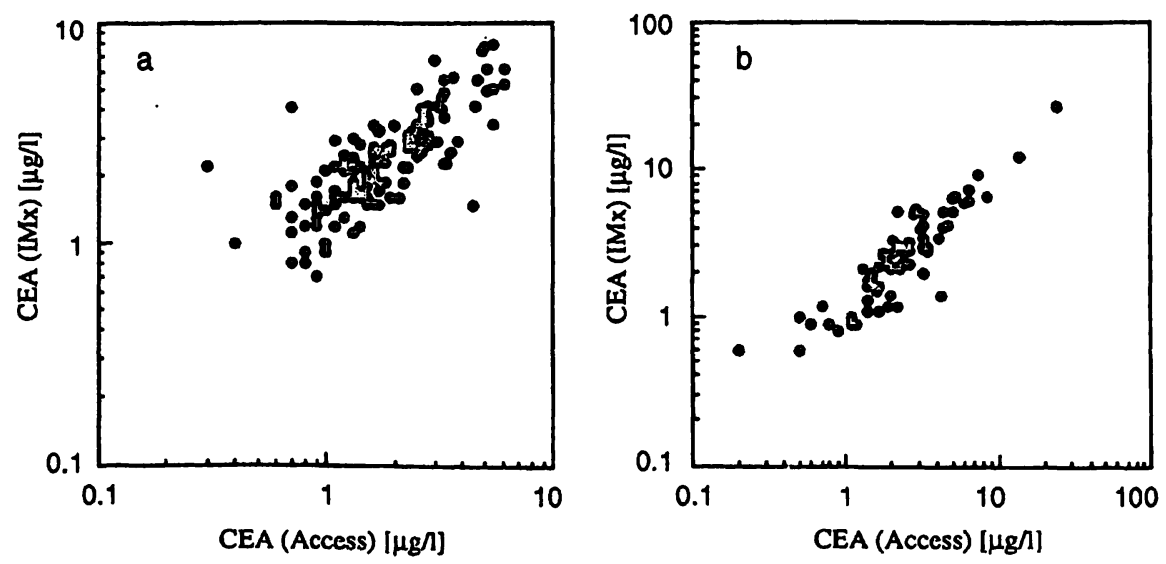

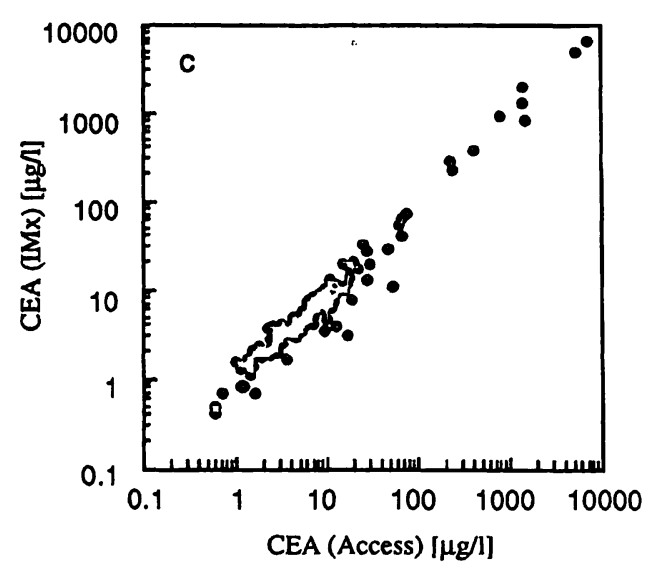

Fig. 4 Correlations of the ACCESS CEA (x) and the IMx CEA (y) assays. (a) 157 normal subjects, $y=0.952 x+0.682$, $r=0.812$, (b) 72 patients with benign disorder, $y=1.047 x$

prominently increased positive rates were observed with the ACCESS CEA assay. The total false positive rate (11.1\%) for benign disease with the ACCESS CEA assay was certainly lower than that with the IMx CEA assay $(19.4 \%)$. Relatively high false positivities with the IMx CEA assay were observed in sera from patients with gastric disease, liver disease or diabetes mellitus.

Tab. 4 Positivity of serum CEA in 205 patients with malignant or benign disease and 157 normal subjects determined with ACCESS CEA or IMx CEA.

\begin{tabular}{|c|c|c|c|}
\hline Diagnosis & $\begin{array}{l}\text { No. } \\
\text { of cases }\end{array}$ & $\begin{array}{l}\text { Access }^{\circledR} \\
\text { CEA } \\
>5.0 \mu \mathrm{g} / 1 \\
\mathrm{n}^{*}(\%)\end{array}$ & $\begin{array}{l}\mathrm{IMx}^{\circledR} \\
\mathrm{CEA} \\
>5.0 \mu \mathrm{g} / \mathrm{l} \\
\mathrm{n}^{*}(\%)\end{array}$ \\
\hline Malignant disease & 133 & $75(56.4)$ & $65(48.9)$ \\
\hline Oesophageal cancer & 10 & $4(40.0)$ & $4(40.0)$ \\
\hline Gastric cancer & 31 & $18(58.1)$ & $15(48.4)$ \\
\hline Colorectal cancer & 26 & $17(65.4)$ & $15(57.7)$ \\
\hline Hepatoma & 14 & $11(78.6)$ & $7(50.0)$ \\
\hline Pancreatic cancer & 6 & $4(66.7)$ & $4(66.7)$ \\
\hline Lung cancer & 11 & $9(81.8)$ & $8(72.7)$ \\
\hline Breast cancer & 20 & $12(60.0)$ & $12(60.0)$ \\
\hline Cervical cancer & 9 & $0(0.0)$ & $0(0.0)$ \\
\hline Ovarian cancer & 6 & $0(0.0)$ & $0(0.0)$ \\
\hline Benign disease & 72 & $8(11.1)$ & $14(19.4)$ \\
\hline Gastric disease & 13 & $0(0.0)$ & $4(30.8)$ \\
\hline Chronic gastritis & 8 & $0(0.0)$ & $2(25.0)$ \\
\hline Gastric ulcer & 3 & $0(0.0)$ & $1(33.3)$ \\
\hline Gastric polyp & 2 & $0(0.0)$ & $1(50.0)$ \\
\hline Colorectal disease & 7 & $1(14.3)$ & $1(14.3)$ \\
\hline Acute colitis & 2 & $1(50.0)$ & $1(50.0)$ \\
\hline Ulcerative colitis & 2 & $0(0.0)$ & $0(0.0)$ \\
\hline Crohn's disease & 3 & $0(0.0)$ & $0(0.0)$ \\
\hline Liver disease & 34 & $3(8.8)$ & $4(11.8)$ \\
\hline Chronic hepatitis & 25 & $2(8.0)$ & $3(12.0)$ \\
\hline Liver cirrhosis & 9 & $1(11.1)$ & $1(11.1)$ \\
\hline Pancreatic disease & 2 & $0(0.0)$ & $0(0.0)$ \\
\hline Pancreatitis & 2 & $0(0.0)$ & $0(0.0)$ \\
\hline Uterine disease & 4 & $0(0.0)$ & $0(0.0)$ \\
\hline Myoma uteri & 4 & $0(0.0)$ & $0(0.0)$ \\
\hline Diabetes mellitus & 12 & $4(33.3)$ & $5(41.7)$ \\
\hline Normal subjects & 157 & $7(4.5)$ & $12(7.6)$ \\
\hline
\end{tabular}

* Numbers of positives.
$+0.133, r=0.962$, and (c) 133 patients with malignant disease, $y=1.001 x+1.088, r=0.995$

In sera from normal individuals, the ACCESS CEA assay gave a decreased false positive rate $(4.5 \%)$ as compared with the IMx CEA assay (7.6\%).

\section{Discussion}

Group $\mathrm{F}$ anti-CEA monoclonal antibodies have been found to recognize the protein epitopes present on domain $\mathrm{B} 3$ of the CEA molecule and to discriminate CEA in tumour tissues from the CEA-related normal antigens (13). By using a group F monoclonal antibody as tracer antibody, Kuroki et al. have developed a new radioimmunoassay and an EIA with increased tumour specificity and independence from the carbohydrate structure of the CEA molecule $(10,15)$. Although those assay systems revealed improved features in cancer sensitivity and efficiency in clinical trials $(14,15)$, it has been impossible to employ those assays on the fully automated immunoassay analyzers. In the present study, by using two defined monoclonal antibodies with higher specificity and affinity for CEA, we tried to establish a new immunoassay for CEA, designated ACCESS CEA, which is adapted to the fully automated ACCESS ${ }^{\circledR}$ immunoassay analyzer.

The ACCESS CEA assay employed a one step sandwich-type method using a combination in which monoclonal antibody F82-61 from group $C$ was used as the capture and monoclonal antibody F11-39 from group F as the tracer antibody. Each monoclonal antibody recognizes an epitope present on the $\mathrm{N}$-terminal domain $(\mathrm{N})$ or C-terminal domain (B3) of the CEA molecule, respectively $(11,12)$, suggesting that the ACCESS CEA assay detects only the whole CEA molecules with both terminal domains.

The assay range of the ACCESS CEA assay was 0.04$1000 \mu \mathrm{g} / \mathrm{l}$ of CEA and the possible high-dose hook effect was prevented up to $100000 \mu \mathrm{g} / \mathrm{l}$ in the working range of the assay. The evaluation of assay performance, such as reproducibility, recovery and dilution tests, and 
interference studics demonstrated the excellent performance of the ACCESS CEA assay.

Since many CEA-related antigens have been found in various tissues unrelated to malignant diseases (1), the discrimination of CEA from the normal related antigens, especially from normal faecal antigen-2 in normal adult faeces, seems to be essential for a CEAassay system (5). Although non-specific cross-reacting antigen-2 is a foetal type of CEA $(20,26)$ and has not yet been found in any normal tissues or tumour tissues, the reactivity with this antigen was also tested in this study. No reactivity of the ACCESS CEA assay with NCA, NFA-1, NFA-2, and NCA-2 indicates that this assay system is able to distinguish CEA from the related normal antigens.

The independence of a CEA-assay system from the influence of variations in the sugar chains of the CEA molecule also seems to be very important, because apparent variation in CEA determination appeared to be mainly due to variation in the structures of carbohydrate chains (8). Furthermore, the expression of epitopes on the sugar chains of the CEA molecule is changeable during synthesis and secretion of CEA by tumour cells, and thus is unstable during the course of malignancy (27). This may result in false apparent fluctuations of the CEA level in the course of diseases unless the assay system is independent of carbohydrate epitopes. The ACCESS CEA assay showed quite homogeneous reac-

\section{References}

1. Thompson JA, Grunert F, Zimmermann W. Carcinoembryonic antigen gene family: molecular biology and clinical perspectives. J Clin Lab Anal 1991; 5:344-66.

2. Goldenberg DM. Carcinoembryonic antigen: its role as a marker in the management of cancer. $\mathrm{Br}$ Med $\mathrm{J} \mathrm{1981 \text {; }}$ 282:373-5.

3. Klee GG, Dodge LA, Reynoso G. Discrepancies in carcinoembryonic antigen measurements: survey and control values vs values for patients. Clin Chem 1987; 33:563-6.

4. Pilo A, Zuchelli GC, Chiesa MR, Masini S, Ferdeghini M. Anomalous between-laboratory variability in a collaborative study of carcinoembryonic antigen immunoassay. Clin Chem 1987; 33:1694-5.

5. Kuroki M, Haruno M, Arakawa F, Wakisaka M, Matsuoka Y. Reaction profiles of seven enzyme immunoassay kits for carcinoembryonic antigen (CEA) analyzed with purified preparations of CEA and related normal antigens. Clin Biochem 1992; 25:29-35.

6. Yamashita K, Totani K, Kuroki M, Matsuoka Y, Ueda I, Kobata A. Structural studies of the carbohydrate moieties of carcinoembryonic antigens. Cancer Res 1987; 47:3451-9.

7. Miura M, Fukuyama $Y$, Hirano $T$, Hirano $M$, Matsuzaki $H$, Oka $\mathrm{H}$. Sugar-chain multiformity of human carcinoembryonic antigen: difference between normal and tumor-associated subfractions. Clin Chem 1990; 35:583-4.

8. Matsunaga A, Kuroki M, Higuchi $H$, Arakawa F, Takakura $K$, Okamoto N, Matsuoka Y. Antigenic heterogeneity of carcinoembryonic antigen (CEA) in the circulation defined by monoclonal antibodies against the carbohydrate moiety of CEA and closely related antigens. Cancer Res 1987; 47:56-61.

9. Kuroki M, Koga Y, Matsuoka Y. Monoclonal antibodies to carcinoembryonic antigen: a systematic analysis of antibody spe- tivity with different CEA preparations tested, showing its independence from the effect of variations in the sugar chains of the CEA molecule.

Since the ACCESS CEA assay certainly showed improved features with respect to the reactivities with purified CEA and related antigen preparations and exhibited excellent assay performance, the clinical features of the ACCESS CEA assay, compared with those of the IMx CEA assay, were estimated in this study. For a fair comparison, the same 362 serum samples from patients with malignant or non-malignant disease, as well as from healthy individuals, were simultaneously assayed by the ACCESS CEA and the IMx CEA assays. The improved diagnostic sensitivity of the ACCESS CEA assay is demonstrated in table 4. In comparison with the IMx CEA assay, $7.5 \%$ increases in the diagnostic sensitivity were observed with the ACCESS CEA assay. This was not simply due to an unsuitable cutoff level in the ACCESS CEA assay since the false positive rate with this assay in benign disease or normal subjects was less than that of the IMx CEA assay; that is, the diagnostic specificity $(93.4 \%, 214 / 229$ cases) with the ACCESS CEA assay was also better than that $(88.6 \%$, 203/229 cases) with the IMx CEA assay. The ACCESS CEA assay, however, deserves further evaluation using longitudinal collected serum samples from cancer patients to determine how well CEA levels correlate with clinical course.

cificities by using related normal antigens and evidence for allotypic determinants on carcinoembryonic antigen. J Immunol 1984; 133:2090-7.

10. Kuroki M, Arakawa F, Higuchi H, Matsunaga A, Okamoto N, Takakura K, Matsuoka Y. Epitope mapping of the carcinoembryonic antigen by monoclonal antibodies and establishment of a new improved radioimmunoassay system. Jpn J Cancer Res 1987; 78:386-96.

11. Ikeda S, Kuroki M, Haruno M, Oikawa S, Nakazato H, Kosaki G, Matsuoka Y. Epitope mapping of the carcinoembryonic antigen with various related recombinant proteins expressed in Chinese hamster ovary cells and 25 distinct monoclonal antibodies. Mol Immunol 1992; 29:229-40.

12. Kuroki M, Arakawa F, Haruno M, Murakami M, Wakisaka M, Higuchi $\mathrm{H}$, et al. Biochemical characterization of 25 distinct carcinoembryonic antigen (CEA) epitopes recognized by 57 monoclonal antibodies and categorized into seven groups in terms of domain structure of the CEA molecule. Hybridoma 1992; 11:391-407.

13. Kuroki M, Murakami M, Wakisaka M, Krop-Watork A, Oikawa $S$, Nakazato $\mathrm{H}$, et al. Epitopes predominantly retained on the carcinoembryonic antigen molecules in plasma of patients with malignant tumors but not on those in plasma of normal individuals. Jpn J Cancer Res 1992; 83:505-14.

14. Matsuoka Y, Kuroki M, Okamoto N, Ikeda S, Hara Y, Minamizawa $\mathrm{T}$, et al. Evaluation of a new monoclonal radioimmunoassay system for carcinoembryonic antigen. Jpn J Clin Oncol 1988; 18:97-103.

15. Nagasaki H, Watanabe S, Kuroki M, Matsumoto Y, Murakami $M$, Omoda $N$, et al. An enzyme immunoassay for carcinoembryonic antigen (CEA) with homogeneous reactivity to different CEA preparations and low cross-reactivity with CEA- 
related normal antigens. J Immunol Methods 1993; 162:235-45.

16. Chan DW, editor. Immunoassay automation. An updated guide to systems. San Diego: Academic Press, 1996.

17. Patterson W, Werness P, Payne WJ, Matsson P, Leflar C, Melander $T$, et al. Random and continuous-access immunoassays with chemiluminescent detection by Access automated analyzer. Clin Chem 1994; 40:2042-5.

18. Matsuoka Y, Matsuo Y, Okamoto N, Kuroki M, Ikehara Y. Highly effective extraction of carcinoembryonic antigen with phosphatidylinositol-specific phospholipase C. Tumor Biol 1991; 12:91-8.

19. Kuroki M, Ichiki S, Matsuoka Y. Coproduction of carcinoembryonic antigen and nonspecific cross-reacting antigen by a continuous cell line from a human pancreatic tumor. $J$ Natl Cancer Inst 1982; 69:401-8.

20. Matsuoka Y, Kuroki M, Koga Y, Kuriyama H, Mori T, Kosaki G. Immunochemical differences among carcinoembryonic antigen in tumor tissues and related antigens in meconium and adult feces. Cancer Res 1982; 42:2012-8.

21. Kuroki M, Koga Y, Matsuoka Y. Purification and characterization of carcinoembryonic antigen-related antigens in normal adult feces. Cancer Res 1981; 41:713-20.

22. Kuroki M, Shinoda T. Takayasu T, Koga Y, Matsuoka Y. Immunological characterization and structural studies of normal fecal antigen-1 related to carcinoembryonic antigen. Mol Immunol 1982; 19:399-406.

23. Koga $Y$, Kuroki M, Matsunaga A. Shinoda T, Takayasu T, Matsuoka Y. Further comparative studies on chemical properties of carcinoembryonic antigen in tumor tissues and closely related antigens in adult feces and meconium. Mol Immunol 1985; 22:67-73.

24. Staros JV, Wright RW, Swingle DM. Enhancement by N-hydroxysulfosuccinimide of water-soluble carbodiimide-mediated coupling reactions. Anal Biochem 1986; 156:220-2.

25. Hashida $S$, Imagawa $M$, Inoue $S$, Ruan $\mathrm{K}-\mathrm{H}$, Ishikawa $E$. More useful maleimide compounds for the conjugation of Fab' to horseradish peroxidase through thiol groups in the hinge. $J$ Appl Biochem 1984; 6:56-63.

26. Yamashita K, Totani K, Iwaki Y, Kuroki M, Matsuoka Y, Endo T, Kobata A. Carbohydrate structures of nonspecific cross-reacting antigen-2, a glycoprotein purified from meconium as an antigen cross-reacting with anticarcinoembryonic antigen antibody. Occurrence of complex-type sugar chains with the $\mathrm{Gal} \beta 1 \rightarrow 3 \mathrm{GlcNAc} \beta 1 \rightarrow 3 \mathrm{Gal} \beta 1 \rightarrow 4 \mathrm{GlcNAc} \beta 1 \rightarrow$ outer chains. J Biol Chem 1989; 264:17873-81.
27. Ichiki S, Kuroki M, Matsunaga A, Arakawa F, Okamoto $N$, Matsuoka $Y$. Antigenic alterations of carcinoembryonic antigen involved in the secretion from various human tumor cell lines. Jpn J Cancer Res 1986; 77:1005-11.

Further readings

van Dalen A, Kessler A-C. A multicentre evaluation of tumour marker determinations using the automatic Enzymun-test ${ }^{\circledR}$ systems ES 300 and ES 600/700. Eur J Clin Chem Clin Biochem 1996; 34:377-84.

Conejo JR, Benedito JE, Jiménez A, Menchén MT, Cano J, Granizo V, Larrodera L. Diagnostic value of three tumour markers determined in pleural effusions. Eur $\mathrm{J}$ Clin Chem Clin Biochem 1996; 34:139-42.

Stieber P, Dienemann H, Hasholzner U, Müller C, Poley S, Hofmann K, Fateh-Moghadam A. Comparison of cytokeratin fragment 19 (CYFRA 2l-1), tissue polypeptide antigen (TPA) and tissue polypeptide specific antigen (TPS) as tumour markers in lung cancer. Eur J Clin Chem Clin Biochem 1993; 31:689-94.

Bauernfeind $M$, Wood WG. Evaluation of a fully mechanised immunoassay - Enzymun-test system ES 300 - and comparison with in-house methods for 8 analytes. Eur J Clin Chem Clin Biochem 1993; 31:165-72.

Kruse R, Geilenkeuser W-J, Röhle G. Interlaboratory surveys of the determination of tumour markers - scatter and repeatability of the results. Eur J Clin Chem Clin Biochem 1993; 31:139-46.

Zucchelli GC, Pilo A, Jaworek D, Masini S, Chiesa MR. Immunoassay of CEA, CA 19-9, CA 125, and CA 15-3 on the automated systems ES 300 and ES 600: methodological evaluation from a multicentre collaborative study. Eur J Clin Chem Clin Biochem 1992; 30:875-9.

Stieber P, Nagel D, Ritzke C, Rössler N, Kirsch CM, Eiermann W, Fateh-Moghadam A. Significance of bone alkaline phosphatase, CA 15-3 and CEA in the detection of bone metastases during the follow-up of patients suffering from breast carcinoma. Eur J Clin Chem Clin Biochem 1992; 30:809-14.

\section{Received May 21/July 29, 1996}

Corresponding author: Dr. Masahide Kuroki, First Department of Biochemistry, School of Medicine, Kukuoka University, 7-45-1 Nanakuma, Jonan-ku, Fukuoka 814-80, Japan 
. 